\title{
Modernisasi Shorf Dalam Al Bahtsu Ashorfi Fid Dirosah Lugowiyah 'Arabiyah Haditsah Karya Nasrin Abdullah Syanuf 'Alwani
}

Eka Safitri

safitriexaf@gmail.com

Universitas Jenderal Soedirman

Ihsan Sa'dudin

sadudiinisan@gmail.com

Jurusan Bahasa dan Sastra Arab

IAIN Syekh Nurjati

- Received: 17.03.2019 • Accepted: 02.04.2019 • Published online: 07.05.2019

Abstract: Morphology (shorof) can not be separated from the study of Arabic language. As the determination of Arabic into an international language, the study of classical Arabic language needs to be developed more broadly and integrated with modern linguistics so that Arabic can be learned easily by all people in this modern era. Like Nasrin Abdullah Syanuf's study 'Alwani in Albahtsu Ashorfi Fid Dirosah Lugowiyah' Arabiyah Hadithah regarding modern Arabic morphology (modern shorof) discovered several new rules, among which there is no term التقاء ساكنين; Long Meaning and Origin of Words; Influence of Intonation (النبر) in Arabic Morphology; Substitution of Hamzah with Harkat Panjang; Location of Hamzah at the end of the word after Alif Zaidah; Prular Form فئl ; and taqsir.

Keywords: Shorf, Morphology, Linguistics, Nasrin Abdullah Syanuf Alwani

\section{Pendahuluan}

Bahasa Arab merupakan bahasa yang digunakan oleh bangsabangsa yang tinggal di sekitar sungai Tigris dan Furat, dataran Syiria, 
dan jazirah Arabia (Timur Tengah). Seperti bahasa Siryania, Finisai, Assyiria, Babilonia, Ibrania, dan Arabia. Dari sekian bahasa di atas yang dapat bertahan sampai sekarang di antaranya bahasa Arab dan Ibrani. Diperkirakan bahwa bahasa Arab adalah cabang bahasa Semit yang paling mendekati bahasa aslinya, karena bangsa Arab tidak banyak bergaul dengan bangsa- bangsa lain dan tidak pernah klasik di bawah kekuasaan bangsa asing (Iskandari \& 'anani, 1916).

Bahasa Arab sebagai bahasa internasional seperti halnya bahasa Inggris. Oleh karena itu, di samping untuk keperluan agama, bahasa Arab juga dapat digunakan sebagai media komunikasi biasa dalam pergaulan bangsa-bangsa (Abidin \& Satrianingsih, 2017). Bahasa Arab bukan hanya milik bangsa atau orang Arab saja. Bahasa Arab adalah bahasa ibu bagi sekitar 300 juta orang di seluruh dunia dan merupakan bahasa resmi di 27 negara (Gazali, 2014).

Banyak kosakata dalam bahasa Arab yang muncul sebagai hasil dari kebudayaan Islam dan banyak istilah- istilah dalam bahasa Arab yang pada masa para Islam belum ada. Ini semua terjadi karena fungsi bahasa Arab di antaranya adalah sebagai bahasa agama islam, bahasa ilmu pengetahuan, bahasa perdagangan, dan lainnya. Karenanya bahasa Arab membuka diri untuk berkembang dari segi kekayaan kosakata dan keilmuannya.

Salah satu ilmu yang mempelajari pembentukan kata adalah morfologi. Dengan ilmu ini, dapat diketahui asal usul pembentukan satu kata, dari satu bentuk kata ke bentuk kata lainnya (derivasi). Dewasa ini, materi morfologi berkembang mengikuti perkembangan zaman. Tidak lagi berkutat pada tema pembahasan morfologi klasik, namun berusaha membuka wawasan baru yang dikiranya masuk dalam pembahasan morfologi. Oleh karena itu, makalah ini akan sedikit membahas tentang morfologi Arab modern berdasarkan pemikiran Nasrin Abdullah Syanuf 'Alwani dalam bukunya Albahtsu Ashorfi Fid Dirosah Lugowiyah 'Arabiyah Haditsah ('Alwani, 2003)

\section{Metode}

Penelitian ini merupakan penelitian kualtatif dan bersifat library research (studi pustaka) dengan objek penelitian kitab Albahtsu Ashorfi 
Fid Dirosah Lugowiyah 'Arabiyah Haditsah karya Nasrin Abdullah Syanuf 'Alwani . Sumber data penelitian terbagi ke dalam dua jenis, sumber data primer dan sumber data sekunder. Sumber data primer diambil dari Albahtsu Ashorfi Fid Dirosah Lugowiyah 'Arabiyah Haditsah karya Nasrin Abdullah Syanuf 'Alwani. Adapun sumber data sekunder penelitian ini berupa naskah, buku, dan hasil penelitian lainnya yang memiliki kesesuaian topik kajian. Metode analisis data yang digunakan adalah metode deskriptif analisis, yaitu mendeskripsikan serta menganalisis data yang ditemukan dari objek penelitian dan literatur lainnya.

\section{Hasil dan Pembahasan}

\section{a. Morfologi Arab}

Secara etimologi shorof bermakna perubahan (تغيير), seperti dalam firman Allah swt.

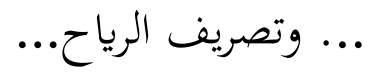

Artinya: perubahan angin dari satu keadaan menuju keadaan lain atau dari satu arah ke arah lain (Al-Quran, 2: 164).

Sedangkan menurut istilah shorof adalah sebuah disiplin ilmu yang membahas perubahan kata dalam bahasa Arab sebelum masuk di dalam susunan kalimat (Al-Ghalayaini, 1994). Sisi lain Abu Hasan Ibn Hasyim Al Kailani dalam Syarh al- Kailani mengatakan bahwa shorof adalah

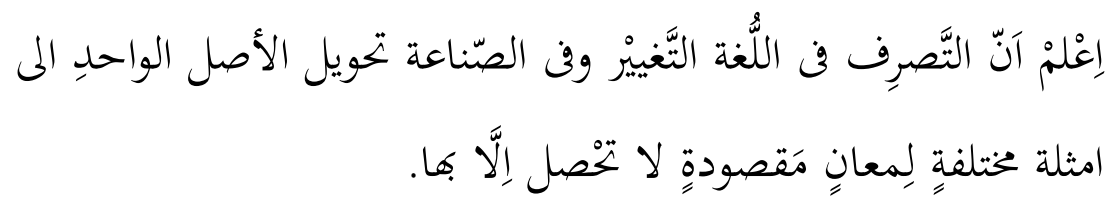

“Taşrif menurut bahasa berarti mengubah, sedangkan menurut istilah adalah mengubah bentuk asal kepada bentuk - bentuk lain untuk mencapai arti yang dikehendaki yang hanya bisa tercapai dengan adanya perubahan."

Ilmu shorof termasuk ilmu tata bahasa Arab yang penting karena menjadi pedoman untuk mengetahui bentuk kalimat, tashgir, nisbat, 
jamak, i'lal, idgham, ibdal, dan lainnya (Busyro, 2003). Selain ilmu shorof, ada disiplin ilmu tata bahasa lainnya dalam bahasa Arab yang berhubungan erat dengan shorof, yaitu ilmu nahwu. Hubungan ilmu shorof dengan ilmu nahwu tidak dapat dipisahkan bagaikan ibu dan

bapak yang saling melengkapi dan membutuhkan. Ada perkataan sebagian ulama

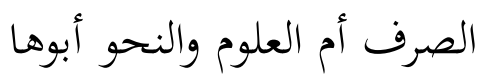

Artinya: ilmu shorof merupakan induk segala ilmu dan nahwu adalah bapaknya.

\section{b. Morfologi Nasrin Abdullah Syanuf 'Alwani}

Terdapat beberapa pembahasan morfologi Arab modern yang dikaji oleh Nasrin Abdullah Syanuf Al'alwani dalam bukunya Albahtsu Ashorfi Fid Dirosah Lugowiyah 'Arabiyah Haditsah ('Alwani, 2003), di antaranya:

\section{1) Tidak ada التقاء ساكنين}

Pakar bahasa dahulu berpandangan bahwa tidak ada التقاء ساكنين dalam satu kata kecuali berada dalam dua keadaan, harkat akhir kata tersebut adalah sukun dan berada di tengah kata (huruf sebelumnya huruf mad dan huruf kedua diidghamkan) seperti contoh kata دآبّة .

Sedangkan pakar bahasa modern berpandangan bahwa التقاء ساكنين itu benar- benar tidak ada, karena itu semua terjadi disebabkan tulisan Arab saja. Hal ini berbanding lurus dengan pendapat mereka yang mengatakan tidak ada perbedaan antara huruf 'illat $(\mathrm{s}, \mathrm{g}$,$) . Topik$ al-Ashwat dalam pembelajaran bahasa Arab mempunyai peranan yang sangat penting. Beberapa literatur menyatakan bahwa mempelajari dan mengkaji al-Ashwat didahulukan sebelum mempelajari dan mengkaji komponen atau keterampilan kebahasaan lainnya (Mufidah \& Zainudin, 2018). Huruf mad yang mempunyai harkat panjang bukanlah disebut huruf sakinah, karena harkat itu 
bukanlah dengan sukunnya melainkan dengan hurufnya. Sebagaimana yang diketahui pada umumnya huruf alif mad dibaca panjang karena harkat fatah bukan karena harkat sukunnya. Contoh kata باب, huruf alif dalam kata itu dibaca panjang bukan karena ada harkat sukun melainkan adanya harkat fatah yang dibaca panjang. Selanjutnya adalah huruf ya mad dibaca panjang karena harkat kasrah bukan karena harkat sukunnya. Contoh kata 5, , huruf ya pada kata di atas dibaca panjang bukan karena ada harkat sukunnya tapi adanya harkat kasrah yang dibaca panjang. Kemudian, huruf wawul mad, dibaca panjang karena ada harkat dhomah yang dibaca panjang, contoh kata موسى. Semua pendapat ini diamini oleh ahli bahasa Arab karena mereka meyakini bahwa harkat-harkat itu bagian dari huruf mad dan penulisan khas Arab yang menempatkan huruf- huruf mad itu terlihat mati (dengan harkat sukun).

\section{2) Harkat Panjang dan Asal Kata}

Hal yang sudah biasa dalam pemikiran ilmu morfologi klasik ketika mengatakan huruf konsonan merupakan harkat dan sebuah harkat tidak ada lambang tulisannya. Kemudian, pendapat lainnya yang mengatakan mad $(,$, ,) berharkat panjang dan bukan huruf. Contohnya huruf Wawu pada kata يدعو bukan sebuah harkat, begitu juga dengan huruf alif pada kata يسعى dan huruf ya pada kata يرعي. Para pakar bahasa klasik tidak berpendapat bahwa harkat dhomah bagian dari huruf wawu, kasrah bagian dari huruf ya, dan fatah bagian dari huruf alif.

Kejadian seperti di atas berbeda sekali keadaannya ketika pendapat ahli bahasa modern yang membagi bunyi konsonan menjadi dua jenis, yaitu yang berharkat pendek (fatah, dhomah, dan kasrah) dan berharkat panjang (alif, wawu, dan ya).

\section{3) Pengaruh Intonasi (النبر) dalam Morfologi Arab}

Intonasi ini merupakan istilah linguistik modern, para pakar bahasa modern telah berusaha menjelaskan permasalahan intonasi ini 
dengan jelas seperti memendekkan harkat yang panjang, bisa juga memanjangkannya, atau menghapusnya. Dalam buku lahnul 'ammah watathowwurul lughowi disebutkan bahwa intonasi adalah penekanan bagian tertentu dalam satu kata sehingga menghasilkan perbedaan bunyi namun jelas ketika di pendengaran.

Penekanan ini menghasilkan suara yang beragam, bisa panjang atau tinggi tergantung dari kuatnya tekanan pada kata tersebut. Sedangkan istilah intonasi menurut linguis modern adalah tinggi rendahnya nada pada kalimat yang memberikan penekanan pada kata- kata tertentu di dalam kalimat. Di antarnya dengan cara menahan udara yang keluar dari paru- paru ketika menyempitnya otot-otot di rongga dada. Kemudian, apabila hendak meninggikan suara adalah dengan menguatkan otot- otot di pangkal tenggorokkan ketika hendak mengucapkan kata tersebut.

Samir Salum memberikan definisi yang beragam mengenai intonasi ini (A'zawi, 2000), di antaranya:

a) Intonasi merupakan serangkaian aktivitas fonologi yang menekankan pada unsur bunyi tertentu dalam pengucapan kata.

b) Intonasi adalah sebuah aktivitas seluruh anggota ucap pada satu waktu, penekanan pada bagian atau seluruh kata sehingga menghasilkan bunyi yang jelas di pendengaran.

c) Intonasi merupakan sebuah usaha kuat dari otot dengan cara menekan atau mempersempit.

Ada benang merah dari semua istilah di atas yaitu intonasi membutuhkan kerja lebih dari otot- otot anggota badan. Junza berpendapat mengenai hal ini, intonasi merupakan pengerahan semua kemampuan artikulator pembicara ketika mengucapkan sebuah kata atau kalimat, dan kejelasan bunyi dari pembicara tergantung kepada karakteristik alami dari penutur ketika mengucapkan. Karena menurutnya satu bunyi itu bisa berbeda tergantung pada tiga aspek ini, yaitu aspek penekanan, tingkatan, dan bentuknya. Ketiga aspek ini berlandaskan pada cara penggunaan alat bantu ucapnya. 
Sedangkan النبر atau intonasi dalam pandangan ulama klasik adalah penekanan pada satu huruf atau meninggikan bunyi pada satu kata. Kemudian, banyak istilah yang digunakan para ahli bahasa klasik dalam menjelaskan النبر ini, di antaranya irtikaz wa tadh'if, ulwush shout, alburuz wa tawatur, wa dhogthu, dan mathalul harkat.

\section{4) Penggantian Hamzah dengan Harkat Panjang}

Ahli bahasa modern berpandangan bahwa tidak ada konsep ibdal antara huruf hamzah dengan huruf mad tapi hamzahnya dihilangkan dan memanjangkan harkat sebelumnya. Hal ini sejalan dengan pendapat sebelumnya yang mengatakan tidak ada hubungan antara huruf 'illah dengan hamzah. Namun untuk menganalisa keduanya itu harus mendalami ketiga bentuk di bawah ini, yaitu:

a) Menghilangkan hamzah dan memanjangkan harkat sebelumnya.

b) Menghilangkan hamzah karena bertemunya dua harkat panjang sebelumnya, seperti wawu, ya, atau alif.

c) Penghilangkan hamzah dan menggantinya dengan menggabungkan dua harkat sebelum atau sesudahnya.

Bertil Malmberg berpendapat bahwa jika ada hamzah terletak antara satu harkat dan satu huruf maka harus disamarkan, bahkan bisa dihilangkan atau harkat sebelumnya dipanjangkan (Malmberg, 1985). Abdu Shobur Syahin menyatakan ada beberapa 'illatnya hamzah, yaitu:

a) Bangsa Arab sedikit menggunakan pengucapan rangkaian kata yang terlalu terbuka dan bahkan berusaha menutup pengucapan kata tersebut dengan cara mematikan huruf (sukun) atau meng idghamkan.

b) Bangsa Arab tidak menyukai rangkaian harkat yang banyak sehingga mereka kesulitan dalam pengucapan. Hal ini sejalan dengan pendapat Ibnu Jini.

c) Beberapa kabilah Arab menghindari harkat- harkat yang panjang dengan cara menyamarkan dan menekan panjangnya pada kondisi tertentu. 


\section{5) Letak Hamzah di ujung Kata Setelah Alif Zaidah}

Ahli bahasa klasik mengatakan bahwa huruf 'illat yang berharkat sukun di ujung akan menjadi huruf ya, wawu, atau alif. Apabila terdapat huruf alif dan setelahnya ada huruf wawu atau ya di ujung kata, maka huruf wawu dan ya diganti menjadi hamzah. Contoh kata

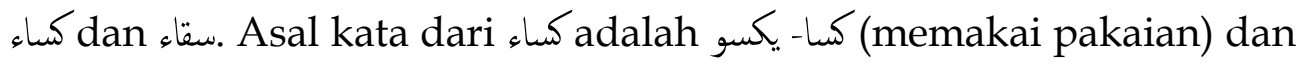
dan apabila dimasukkan kata ganti "saya" dalam

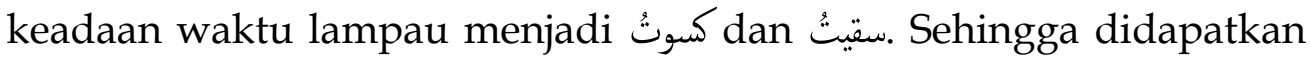

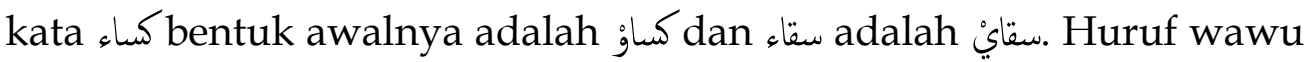
dari سقائ dan huruf ya dari danti dengan huruf alif karena keadaan harkat sebelumnya (pada kata كساو dan سقائ) adalah fatah, sehingga menjadi كساi dan waka bertemulah dua huruf alif yang mati (satu huruf asli dan satunya huruf pengganti dari wawu dan ya). Huruf alif pengganti (wawu dan ya) diganti dengan huruf hamzah karena kedekatan huruf yang menerima harkat.

Pada hakikatnya dari kedua contoh di atas tidak terjadi pertemuan dua harkat mati karena huruf alif di sana tidak mati melainkan berharkat panjang dan yang terjadi pada kedua kata itu adanya harkat ganda di akhir kata, سقائ dan سماو. Harkat ganda tersebut berupa fatah panjang dan huruf wawu dan ya yang bersukun, sehingga keduanya menyerupai harkat.

\section{6) Bentuk Prular فيائل}

Linguis bahasa Arab klasik berpendapat bahwa huruf wawu dan ya diganti dengan hamzah ketika posisinya setelah alif jamak pada shigah مفاعل karena bertemunya dua huruf mati. Seperti dua kata ini, صحايف Bentuk asal dari kedua kata itu adalah , عجاوز, namun karena bertemu dua huruf mati (huruf alif dan ya pada kata صحايف; huruf alif dan wawu pada kata عجائز) maka diganti dengan hamzah dan jadilah صحائف dan عجائز. 
Menurut Abdu Shobur Syahin hal serupa juga terjadi pada kata قائل Asal kedua kata tersebut adalah بائع dan بائ danun karena bangsa Arab kesulitan dalam mengucapkan konsonan lemah maka huruf wawu pada kata قاول dan huruf ya pada kata بايع diganti dengan hamzah sehingga menjadi قائل dan بائع.

\section{7) Taqsir}

Pada istilah linguis klasik ada istilah penghilangan huruf mad (ا,و, karena bertemu dua huruf mati. Huruf mad atau vokal dihilangkan apabila setelah itu ada huruf konsonan yang berharkat sukun, sehingga ada dua huruf mati yang bertemu. Pendapat ini bertolak belakang dengan linguis modern yang mengatakan bahwa huruf mad itu tidak mati melainkan berharkat panjang sehingga tidak ada istilah bertemunya dua huruf mati. Para linguis klasik berpendapat seperti itu karena mereka terjebak oleh tulisan Arab. Ada pendapat Khalil yang mengatakan bahwa sukun dan harkat berkaitan erat dengan konsonan bukan dengan vokal.

\section{Simpulan}

Pembahasan morfologi arab modern terbagi menjadi tiga kajian, yaitu kajian morfologi taysir, studi sejarah dan perbandingan morfologi Arab, dan studi linguistik ilmiah bagi morfologi Arab. Ketiga kajian di atas merupakan hasil dari metode deskriptif dan interkoneksi antara studi morfologi dengan fonologi. Morfologi taysir belum memberikan pembaharuan yang baru dalam morfologi Arab, meskipun ada pembaharuan itu pun baru sedikit karena peneliti bahasa terbatas pada meringkas, menjelaskan, mengomentari, bahkan menghapus kaidah yang sudah ada. Maksud dari morfologi taysir di sini adalah memberikan pembahasan baru seperti memadukan morfologi dengan fonologi sehingga dapat menyentuh esensi dan karakter dari bahasa tersebut.

Para ahli nahwu (grammarian bahasa Arab) belum memahami seluk beluk bahasa di berbagai daerah sehingga mereka belum bisa memberikan studi perbandingan bahasa Arab dengan bahasa daerah 
lainnya di Jazirah Arab. Para ahli nahwu belum bisa membedakan antara kebenaran deskriptif dengan kebenaran perbandingan sejarah .

Munculnya ilmu bahasa yang bersifat perbandingan sejarah di akhir abad delapan belas dan berkembang pesat di abad sembilan belas memberikan pengaruh besar terhadap peneliti Arab di bidang studi morfologi. Para peneliti Arab menafsirkan dan menjelaskan morfologi Arab dengan metode perbandingan sejarah kemudian menyajikannya dengan penjelasan fiksi namun logis untuk setiap permasalahannya.

Metode deskriptif mulai digunakan para ahli nahwu Arab dengan memadukan filsafat dan logika. Pada abad dua puluh mulai berkembang metode deskriptif yang berbasis pada metode deskriptif bangsa Arab klasik. Pada abad kedua puluh peneliti bahasa modern mulai memadukan studi morfologi dengan fonologi. Hal ini yang belum menjadi perhatian grammarian Arab klasik. Pakar bahasa modern mulai memberikan kritikan terhadap kajian morfologi Arab klasik dengan memadukannya pada fonologi (lebih memperhatikan aspek pengucapan dibandingkan aspek tulisan) dalam menjelaskan permasalahan- permasalahan morfologi Arab.

Para linguis Arab modern berpandangan bahwa huruf mad ) bukan huruf mati melainkan mempunyai harkat panjang dan tidak ada istilah pertemuan dua huruf mati sebagaimana penjelasan linguis klasik. Linguis modern merujuk kepada penjelasan bunyi yang berhubungan dengan struktur kalimat bahasa Arab. Di antara catatan tentang morfologi modern yang diberikan oleh Nasrin adalah tidak ada substitusi (ibdal) antara تاء افتعال dan dengan wawu dan ya apabila tidak ada hubungan bunyi antara huruf ta (huruf shahih) dengan huruf wawu dan ya berharkat panjang; tidak ada hubungan bunyi antara hamzah dengan huruf mad (ا, و, ي) karena hamzah merupakan konsonan sedangkan huruf mad berharkat panjang. Hal ini menjadi bahan kekeliruan pada penjelasan- penjelasan linguis klasik dalam bab bidal hamzah min ahrufil 'illah dalam kajian morfologi Arab; bunyi huruf rangkap (bertasydid) harus dikaji dari aspek bunyi huruf; tidak ada istilah 'ilal dengan cara memindahkan ('ilal bin naqli) dalam 
pandangan linguis modern. Namun dihilangkannya harkat panjang (, و ي) dan menggantinya dengan harkat yang pendek.

Kemudian dia juga menambahkan bahwasanya huruf hamzah menghilangkan huruf mad dan menggantinya dengan harkat panjang; huruf hamzah tidak mengubah huruf- huruf sahih melainkan menghapus dan menggantinya; huruf mad tidak dihilangkan ketika bertemunya dua harkat mati karena huruf mad mempunyai harkat, harkat panjang; dan meninggalkan الوزن الإيقاعى dan menggunakan الوزن خطايا Contoh, lebih baik menggunakan wazan فعالى buat kata مفاعل (pendapat linguis modern) daripada mendasarkan pada wazan (pendapat ahli bahasa klasik).

\section{Referensi}

'Alwani, N. A. S. (2003). Al Bahtsu Ashorfi Fid Dirosah Lugowiyah 'Arabiyah Haditsah. Ibn Rusydi Jamiah Bagdad.

A'zawi, I. W. Al. (2000). At-Tangim Al-Lughawi Fi Al-Qur'an Al-Karim (1 ed.). Oman: Dar Ad-Diya.

Abidin, Z., \& Satrianingsih, A. (2017). Perkembangan Dan Masa Depan Bahasa Arab. Diwan: Jurnal Bahasa dan Sastra Arab, 3(2), 142. https:// doi.org/10.24252/ diwan.v3i2.4459

Al-Ghalayaini, M. (1994). Jami' Ad-Durus Al-'Arabiyah. Beirut: Mansurot Al Maktabah Al' Ashriyah.

Busyro, M. (2003). Shorof Praktis Metode Krapyak. Yogyakarta: Menara Kudus.

Gazali, E. (2014). Alih Aksara 'G' dan 'Ng' dalam Nama Indonesia Ke Bahasa Arab. In Prosiding Seminar Tahunan Linguistik (SETALI) : Keragaman Budaya Dalam Bingkai Keragaman Bahasa. (hal. 179-183). Bandung: Prodi Lingusitik SPs UPI.

Iskandari, ahmad al, \& 'anani, M. (1916). Al- Wasith fil adabil 'arabi wa tarikhihi. Gontor: Gontor Darussalam.

Malmberg, B. (1985). 'Ilm Al-Ashwat. Mesir: Maktabah As-Syabab AlMuniroh. 
Eka Safitri, Ihsan Sa' dudin

Mufidah, N., \& Zainudin, I. (2018). Metode Pembelajaran Al-Ashwat. al Mahara Jurnal Pendidikan Bahasa Arab, 4(2), 199-218. 